\title{
Serbest Deoksiribonükleik Asit Analizinde Preanalitik Aşamanın Önemi
}

\author{
Importance of Preanalytical Phase in Cell Free Deoxyribonucleic Acid Analysis
}

\author{
Burak ARSLAN (iD, Aylin SEPİCI DİNÇEL (iD)
}

öz

Laboratuvar, klinik tanıya karar verme aşamasında çok önemli bir yere sahiptir. Pre-preanalitik (test istemi), preanalitik (numunelerin toplanmasi), analitik (numune analizi), postanalitik (sonuç raporlama), post-post analitik (sonuç değerlendirme) süreçler gibi birbiri içerisine geçmiş fazlar, laboratuvar süreçlerini oluşturup, numune toplanmasından analizine kadar geçen süreçte kendi içlerinde ayrı öneme sahiptirler. Laboratuvar hatalarının $\% 70$ 'den fazlasını preanalitik aşamada meydana gelen hatalar oluşturmaktadır. Bu hataların azaltılması veya en aza indirgenmesi analiz sonuçlarının daha doğru ve güvenilir olmasını sağlayacaktır. Rutin laboratuvar pratiğinde olduğu kadar bilimsel araştırmalarda ve belki de ileride rutin laboratuvar pratiğine girecek olan serbest deoksiribonükleik asit gibi biyobelirteç analizlerinde de preanalitik aşama çok önemlidir ve halen süreç optimizasyonu yapılmamıştır. Analiz öncesi dönemde, hangi aşamaların analizi etkileyebileceği yönündeki araştırmalar analiz sonuçlarını değerlendirme aşamasında yol gösterici olacaktır. Çünkü, analiz için kullanılan tüp seçiminden, numuneyi santrifüj etme hızına kadar birçok analiz öncesi aşamada laboratuvarlar, kendi benimsedikleri metotları ve prosedürleri kullanmaktadırlar. Derlemede, serbest deoksiribonükleik asit analizi öncesi hata kaynakları sebeplerinden bahsedilmiştir.

Anahtar Kelimeler: Serbest deoksiribonükleik asit, Preanalitik Aşama, Süreç Optimizasyonu

\begin{abstract}
The laboratory plays an important role in the decision-making process of clinical diagnosis. Pre-preanalytical (test order), preanalytical (sample collection), analytical (sample analysis), post-analytical (result reporting), post-post analytical (result evaluation) processes are intertwined phases and these phases form the laboratory processes and are of particular importance in the process from sample collection to analysis. More than $70 \%$ of laboratory errors occur in the pre-analytical phase. Reducing or minimizing these errors will make the analysis results more
\end{abstract}

Aylin SEPİCİ DİNÇEL (凶), Burak ARSLAN

Gazi Üniversitesi Tip Fakültesi, Tibbi Biyokimya Anabilim Dalı, ANKARA

e-mail:asepicidincel@gmail.com accurate and reliable. As well as routine laboratory practice, the pre-analytical phase is very important in scientific research, and perhaps in biomarkers such as cell-free deoxyribonucleic acid that will be introduced into routine laboratory practice in the future, and process optimization has not yet been performed. Because many laboratories use their own adopted methods and procedures in many stages from the selection of tubes used for analysis to the speed of centrifugation of the sample, and as in routine laboratory practice, there is no clear procedure to be used by all world laboratories and reference laboratories. In the future, we will be able to determine the procedures for the most appropriate preanalytical steps with the pre-analytical process management and error detection studies that we will do for our own studies in the pre-analytical phase and with the light of the information in the literature. In this review, the causes of error sources before free deoxyribonucleic acid analysis are mentioned.

Keywords: Cell Free DNA, Preanalytical Phase, Process Optimization

\section{GíRiş}

Laboratuvar, klinik tanıya karar verme aşamasında çok önemli bir yere sahiptir. Pre-preanalitik (test istemi), preanalitik (numunelerin toplanması), analitik (numune analizi), postanalitik (sonuç raporlama), post-post analitik (sonuç değerlendirme) süreçler gibi birbiri içerisine geçmiş fazlar, laboratuvar süreçlerini oluşturup, numune toplanmasından analizine kadar geçen süreçte bu fazlar kendi içlerinde ayrı öneme sahiptirler (1). Laboratuvar hatalarının \%70'den fazlasını preanalitik aşamada meydana gelen hatalar oluşturmaktadır. Bu hataların büyük kısmı hasta hazırlığ 1 , numune toplanması, numune transportu, analiz hazırlığı ve numune depolama aşamasında meydana gelmektedir (2). Bu hataların azaltılması veya minimuma indirgenmesi analiz sonuçlarının daha doğru ve güvenilir olmasını sağlayacaktır. Rutin laboratuvar pratiğinde olduğu kadar bilimsel araştırmalarda ve belki de ileride rutin laboratuvar pratiğine girecek serbest deoksiribonükleik asit 
(serbest DNA) gibi belirteçlerde de preanalitik aşama çok önemlidir ve süreç optimizasyonu yapılmamıştır. Analiz öncesi dönemde hangi aşamaların, analizi etkileyebileceği yönünde ki araştırmalar analiz sonuçlarını değerlendirme aşamasında yol gösterici olacaktır. Çünkü analiz için kullanılan tüp seçimi, numuneyi santrifüj etme hızı ve süresi gibi birçok basamakta laboratuvarlar kendi benimsedikleri metotları ve prosedürleri kullanmakta olup, rutin laboratuvar pratiğinde olduğu gibi net, kullanılması önerilen bir prosedür bulunmamaktadır. Aynı kişiden eş zamanlı alınan kan örneklerinin, farklı preanalitik aşamalardan geçmesi sonucunda, analiz edilen serbest DNA miktarları farklı olabilmektedir. $\mathrm{Bu}$ yüzden serbest DNA analizlerinde preanalitik aşama ve bu aşamadan kaynaklanabilecek hata kaynaklarını bilmek analiz sonuçlarını değerlendirirken yol gösterici olabilecektir.

\section{Tarihçe ve Keşif}

1948 yılında ilk defa insan kanında serbest nükleik asitlerin varlığı tanımlanmış ve 1996 yılında kanser hastalarında serbest DNAüzerinde mikrosatellit değişimler gösterilmiştir. Son yıllarda, kanser hastalarının kanında yüksek konsantrasyonlarda bulunan serbest nükleik asitlere (DNA, mesajcı ribonükleik asit (mRNA), mikroRNA (miRNA)) olan ilgi artarak devam etmiştir. Bilimsel araştırmalarda bu serbest belirteçlerin kan biyobelirteci olarak potansiyel değerlerinden bahsedilmiştir. Plazma veya serumda serbest nükleik asitleri tespit etmek "likit biyopsi" olarak adlandırılmaya başlanmıştır. Likit biyopsiler invaziv tümör biyopsilerinin yerine kullanılabilecek bir yöntem olarak düşünülmeye başlanmıştır. Likit biyopsiler tekrarlayan kan örnekleri alımı ile, hastalığın doğal gidişatını izleyebilme, kanser tedavisine verilen cevabı gözlemleyebilmeye olanak sağlayabilecektir. Serbest nükleik asitler sadece tümöre spesifik değildir, insan vücudunda meydana gelen fizyolojik ve patolojik süreçleri de yansıtmaktadır $(3,4,5,6)$.

Serbest nükleik asitlerin kan, idrar gibi vücut sıvılarındaki miktarları kanserlerde (benign veya malign lezyonlar), inflamatuvar hastalıklarda ve travmada artış göstermektedir. Kanser ve hastalığın gidişatı süresince meydana gelen serbest DNA artışındaki mekanizmalar hala iyi anlaşılabilmiş değildir (7).

Serbest DNA analizi, analizin yapılacağı hastalık grubu seçimi ile başlayıp, çalışlacak hastalık grubuna uygun numune (kan, idrar gibi vücut sıvıları) seçimi, numune toplama tüpü seçimi, uygun numune santrifüjü (bu aşamada, seçilen tüp tipine göre numune eğer kan ise serum veya plazma eldesi olur), depolama (elde edilen süpernatanın hangi sıcaklıkta depolanacağı) ve ekstraksiyon (DNA ekstraksiyonu) aşamalarından oluşur. Numune analizi aşamasında ve DNA ekstraksiyonunda bile henüz tam bir fikir birliği sağlanamamış olan, ama bir biyobelirteç olarak çok büyük umutlar vaat eden "likit biyopsi"nin, analiz öncesi aşamasındaki süreçlerdeki (preanalitik süreçlerin) hataların ve hata kaynaklarının tespit edilip, hataların giderilmesi veya en az hata bulunan protokolle devam edilmesi kaçınılmaz bir gerekliliktir (8).

İnsan kanında serbest DNA'nın keşfinden beri, çoğu çalışma bu biyobelirtecin solid tümörler için diagnostik ve prognostik kullanımına odaklanmıştır. Bazı prenatal testler haricinde serbest DNA analizi henüz klinik pratikte ve rutinde kullanıma girememiştir. Kliniğe adaptasyonun zorluğu daha çok; preanalitik süreçlerdeki hataların giderilememesi, ekstraksiyon ve analiz aşamasında uygulanacak metot farklılıklarından kaynaklanmaktadır. Daha az olarak da; serbest DNA'nın fonksiyonu ve köken aldığı yer hakkındaki bilgi yetersizliği, DNA'nın yetersiz moleküler karekterizasyonu gibi sebeplerdir (9).

\section{Farklı Çalışmalarda Serbest DNA Analizi}

Leon ve arkadaşları 1977 yılında, farklı tipte kanser hastalarında, sağlıklı insanlara göre kandaki serbest DNA düzeylerinin anlamlı olarak artmış olduğunu göstermişlerdir. Ayrıca bu durumun, metastazlı hastalarda daha fazla olduğu belirtilmiştir. Hatta, bu hastalarda radyoterapi aldıktan sonra serbest DNA düzeylerinde dikkate değer bir azalma gösterilmiştir (10). Bu sonuçlar ilk defa kanser hastalığının tespitinde ve tedavisinin takibinde serbest DNA'nın potansiyel bir biyobelirteç olabileceğini göstermiş̧ir. Daha pahalı ve invaziv tanı ve takip metotlarına göre, minimal invaziv bir şekilde elde edilen serbest DNA, invaziv yöntemlerin (biyopsi, cerrahi girişim gibi) yerini alabilecek potansiyel bir biyobelirteç olarak belirtilmektedir. Bazı çalışma grupları, klinik, patolojik bilgiler ve serbest DNA seviyeleri arasında korelasyon bulmamasına rağmen, Leon ve arkadaşlarının yaptığı gözlemle çoğu çalışma benzer şekilde uyumludur (11-16).

Fleischacker ve arkadaşlarının, farklı araştırma grupları tarafından yapılan 50'den fazla çalışmayı özetlediği kapsamlı bir derlemede; çoğu vakada serbest DNA seviyelerinin, kanser hastaları ve sağlıklı kişiler arasında anlamlı olarak farklı olduğu belirtilmiştir (17). Belirtilen 
farkın dışında bazı kafa karıştırıcı bilgilerin de olduğu fark edilmiştir. Kanser hastalarının kanında serbest DNA düzeylerinin değer olarak; mililitrede birkaç nanogramdan birkaç bin nanograma değiştiği görülmüştür. Ayrıca hastalardaki bu değer aralığına uyan, sağlıklı insan sonuçları da olduğu belirtilmiştir (18-21). Aynı değer aralığı arasına giren bu serbest DNA seviyeleri, sağlıklı ve hasta insanları birbirinden ayırt etmeyi oldukça zorlaştıracaktır.

$\mathrm{Bu}$ tutarsızlıklara vurgu yapmak için, van der Vaart ve Pretorius, raporlanmış farklı gruplardaki serbest DNA düzeylerini karşılaştırmışlardır. Burada 100'den fazla grupta, sağlıklı, kanserli ve kanser dışında başka bir hastalığı olanlar kıyaslanmıştır. Sonuçlar incelendiğinde, farklı gruplar arasında serbest DNA konsantrasyonları açısından dikkate değer bir iç içe geçme durumu olduğu gözlenmiştir. $\mathrm{Bu}$ durum, herhangi bir kanser tipi için serbest DNA konsantrasyonları açısından referans aralığı oluşturmayı ve tanı için kesim noktası değeri belirlemeyi neredeyse imkansız hale getirmiştir (22).

Hasta ve sağlıklı bireylerde serbestDNAkonsantrasyonun en düşük ve en yüksek değerleri ve bu değerler arasında kalan sonuçların birbirini kapsamasının olası sebepleri açıklanmıştır. Serbest DNA seviyeleri sabit değildir, uzun ve kısa periyotlar içerisinde ölçüldüğünde sağlıklı ve hasta bireylerde kan seviyeleri dalgalanmalar göstermektedir $(23,24)$. Bu durum, çevresel stresörlere hücresel cevap, sirkadyan ritim, aşırı sigara içiciliği, malign olmayan hastalıklar, egzersiz, kalp yetmezliği gibi durumlara bağlı olabilmektedir. Bütün hücreler kan dolaşımına serbest DNA salabildiği için, kanser hastalarındaki toplam serbest DNA sadece tümör kaynaklı DNA'yı göstermez, bunlar aynı zamanda farklı fizyolojik süreçlerde sağlıklı hücrelerden de salınan DNA'lar olabilmektedir. Ek olarak, malign hücrelerden salınan serbest DNA'ların kan düzeyleri çok yüksek olmak zorunda değildir. Bu durum da beraberinde yanlış pozitif veya yanlış negatif sonuçları getirmektedir (22). Serbest DNA analizinde analitik fikir birliği ve standart çalışma prosedürü bulunmamaktadır. Çalışma grupları arasındaki metot farklılıkları esas olarak DNA izolasyonu ve ölçüm yöntemlerinin seçimine dayanmaktadır (25).

\section{Preanalitik Aşama}

Potansiyel biyobelirteç olan, serbest DNA'nın biyobelirteç olarak kullanılabilmesi için, analitik aşamadaki bu farklılıkları ve sorunları çözmek ne kadar önemliyse, preanalitik aşamadaki hataların da minimuma indirilip, optimum analize hazırlı aşamasından geçmesi gerekmektedir.

Malentacchi ve arkadaşlarının yakın zamanda yayınlanan çalışmasında bu konularla ilgili bazı tespitler vardır. EU SPIDIA (Standardization and improvement of generic pre-analytical tools and procedures for in vitro diagnostics)'nın alt projelerinden birisi olan SPIDIADNAplas projelerinden elde edilen bulgularla ilgili bir rapor yayınlanmıştır. 21 Avrupa ülkesinden 56 katılımcı laboratuvarın katıldığı bir anket formu oluşturulmuştur. $\mathrm{Bu}$ anket formu laboratuvarların kullandıkları kan toplama tüpleri, kullanılan numune miktarı, venöz kan alımı ve işlenmesi, kan işlenmesi ile DNA izolasyonu arasındaki zaman, plazmanın depolama sıcaklığı, DNA izolasyonu ve ölçüm metotları hakkında sorular içermektedir. Farklı laboratuvarların katılım gösterdiği bu çalışmada, laboratuvarlar arasında ciddi yaklaşım farklılıkları olduğu tespit edilmiştir (26).

Anket formuna ilaveten, çalışmayı yürüten merkez laboratuvar, katılımcı diğer laboratuvarlar için, aynı hastadan alınan numunelerden elde edilen plazmayı porsiyonlayıp, çalışmaya katılan katılımcı laboratuvarlara göndermiştir. $\mathrm{Bu}$ katılımcı laboratuvarlarda ekstrakte edilen serbest DNA'lar, tekrar yürütücü merkez laboratuvara gönderilmiş ve burada serbest DNA'ların ölçümleri yapılmıştır. Aynı plazma örneklerinin, farklı laboratuvarlarda ekstraksiyonu sonrasında, serbest DNA konsantrasyonlarının 2,87 ve 224,02 pg/ $\mu \mathrm{L}$ arasında değiştiği görülmüştür (26). Aynı plazma örneğinin analiz öncesi basamaklardan olan ekstraksiyon basamağındaki farklılıklar sebebi ile ne kadar fazla oranda değişebildiği görülmektedir.

Serbest DNA analizi için, numune toplamaya başlamadan önce, seçilecek matriksi (serum, plazma) iyi belirlemek gerekmektedir. Analiz öncesinde örnek türünün ne olacağını belirlemek, farklı örnek türüne ait sonuçları yorumlamayı kolaylaştırabilecektir. Çünkü; farklı klinik alanlarda yapılan çalışmalarda, serum örneklerinde plazmaya göre daha fazla serbest DNA olduğu gösterilmiştir (27). Serbest DNA düzeylerinin serumda plazmaya göre yüksek olması dışında, serumun hastalar arasında daha fazla varyasyon gösterdiği belirtilmiştir (22). Yükselen DNA seviyelerinin genomik DNA kontaminasyonuna da bağlı olabileceği belirtilmiştir. Ayrıca; serum eldesi sırasında alınan kan pıhtılaşma sürecine gitmektedir. Bu süreçte lökositler, hematopoetik hücreler lizise uğramaktadır. Serumda plazmaya göre DNA fragmanlarının yüksek olmasının bir diğer sebebi de bu pıhtılaşma sürecidir $(22,28,29,30,31)$. 
Serum eldesi için; numune alımından sonra pıhtılaşma periyodu vardır ve bu süreç için bir süre beklenmesi gerekmektedir. Pıhtılaşma için koagulasyon kaskatının aktive olmasına bağlı olarak, bu süreç önemli miktarda bilgi verici serbest DNA'ların kaybı ile sonuçlanabilir. Ayrıca, plateletler trombin oluşumunda anahtar rolü olan mikropartikullerinanaüreticisidir.Plazmanın defibrinasyonu bu yüzden platelet kaynaklı mikropartikullerin kaybı ile sonuçlanıp, sonuç olarak daha fazla serbest DNA'nın kaybı ile sonuçlanır (33). Thierry ve arkadaşları plazmanın tümör kaynaklı DNA için uygun bir numune olduğunu söylerken, klinik önemi olan serbest DNA'lar hakkında yapılan çalışmaların birçok vakada serum kullandığını belirtmiştir (34). Serbest DNA konsantrasyonları, plazma örneklerinde serum örneklerine göre daha az değişkenlik gösterir. Hücresel kontaminasyondan etkilenmesi daha az olasılıktadır. Serum ve plazma örnekleri arasında serbest DNA düzeyleri bakımından anlamlı farklar olabilmektedir. Plazma örneklerinin bu sebeple serbest DNA analizleri için kullanılabileceği belirtilmiştir (32).

Serbest DNA'nın niteliksel ve niceliksel analizi için gerekli ön koşul kontamine olmamış başlama materyalidir. Başka bir deyişle, herhangi bir preanalitik aşamada, kullandığımız numune, hücrelerden salınan hücresel DNA ile kirlenmiş olmamalıdır. Chiu ve arkadaşları, kan işleme (santrifüj öncesi ve sonrasında yapılan işlemler) aşamasında takip edilen protokolün total DNA konsantrasyonunu ciddi şekilde etkilediğini göstermişlerdir. Santrifüj öncesinde yapılacak olan mikrosantrifüj ve filtrasyonun, plazmadaki hücresel DNA kontaminasyonuna bağlı yanlış çıkabilecek sonuçları engelleyebileceğini göstermişlerdir (35).

Herrera ve arkadaşları, özofagus kanserli hastalardan alınan depo edilmiş $(819 \mu \mathrm{g} / \mathrm{L})$ ve taze $(13 \mu \mathrm{g} / \mathrm{L})$ örneklerde serbest DNA düzeyleri bakımından ciddi fark olduğunu gözlemlemişlerdir. $\mathrm{Bu}$ farkın esas sebebinin, depolanan örneklerin sadece bir kez santrifüj edilirken (1600 x g, 5 dakika) taze örneklerin iki kere santrifüj edilmiş (1600 x g, 10 dakika) olarak açıklanmıştır (36). Tam tersi olarak Lui ve arkadaşları bir veya iki kez santrifüj etmenin serbest DNA düzeyleri üzerine bir etkisi olmadığını gözlemlemişlerdir. Çalışmanın ileri aşamalarında başka örneklerle çoklu santrifüj uygulamaları ile miktarlandırılan DNA düzeylerinde bir değişiklik olmamıştır (37). Bu yüzden, literatürde santrifüjün serbest DNA düzeylerine etkisi ile ilgili net bir veri bulunmamaktadır. Plazma veya serum, hangi örnek türü kullanılacaksa serbest DNA analizi için muhakkak santrifüj aşamasından geçmek zorundadır.
Preanalitik aşamanın önemli bir parçası olan numune santrifüjü serbest DNA analizlerinde standart bir prosedüre oturtulmak zorundadır.

EDTA (etilendiamin tetra asetik asit), heparin ve sitrat en sık kullanılan antikoagülanlardır. Kanın alınmasından en geç 6 saat içerisinde santrifüj edilmesi ve işleme alınması şartıyla, bu antikoagulanlardan hiçbirinin izole edilen serbest DNA düzeylerini etkilemediği gözlenmiştir. Fakat santrifüj ve işleme süresi 24 saat ve daha uzun bir süreye uzatılırsa, EDTA'nın heparin ve sitrata üstün geldiği saptanmıştır (38). Heparinin polimeraz zincir reaksiyonunu inhibe ettiği belirtilmiş olsa bile (39), bu düşüncenin tam tersi olarak, Messaoudi ve arkadaşları bu durumun eş zamanlı polimeraz zincir reaksiyonu üzerine bir etkisi olmadığını gözlemlemişlerdir (21).

Venöz kan alımı ile kan işleme arasındaki zaman diliminde, süreç uzadıkça serbest DNA konsantrasyonları artmaktadır. Hangi noktadaki gecikmenin serbest DNA konsantrasyonlarında ani pik yapıp değiştirebileceği hala tartışmalıdır. Bazı yazarlar bu artışın 2 saat içerisinde olduğunu belirtirken (40), bazı yazarlar bu durumu 24 saatte kadar uzayabilen süreçlerde tespit ettiklerini rapor etmişlerdir (28). Messaoudi ve arkadaşlarının raporlarına göre 4 saate kadar DNA konsantrasyonu stabil kalırken, 6 saatlik gecikmeden sonra dramatik olarak serbest DNA miktarları artmaktadır (21). Bunun tam tersi, Jung ve arkadaşları 8 saatlik depolamadan sonra serbest DNA konsantrasyonlarında bir artma gözlemlememişlerdir (41). Ek olarak, başka yazarlar santrifüj için geçen 6 saatlik gecikme süresinin konsantrasyon üzerine önemli bir etkisi olmadığını belirtmişlerdir (29,30). Bütün bu araştırmalarda, numunelerin depolama sıcaklığının serbest DNA miktarları üzerine etkisi araştırılmış fakat sonuçların değişmediği görülmüsştür. $-80^{\circ} \mathrm{C}$ 'de 2 hafta depolama ile veya $-20^{\circ} \mathrm{C}$ 'de 4 hafta depolama ve 3 kere dondurma çözdürme döngüsüne sokmanın DNA miktarları üzerine etkisi olmadığı görülmüştür (29).

Swinkels ve arkadaşları, kullanılan kan toplama tüplerinin büyüklüğü, toplanan kan miktarı ve plazmadaki hücresel DNA kontaminasyonu derecesi arasinda korelasyon bulmuşlardır (42). Farklı türlerde toplama tüplerinin analizlere etkisi farklı çalışma gruplarında incelenmiş̧ir. Gautschi ve arkadaşları, serbest DNA'yı plazma veya serumdan izole etmek için Vacutainer veya S-Monovette tüplerinin kullanılmasının verimi etkilemediğini bildirmiştir (16). Aynı durum EDTA ve cellfree DNA ${ }^{\text {TM }}$ kan toplama tüplerinde de, kan alımından sonra 
hemen işleme alınan örnekler için kıyaslama yapıldığında gözlenmiştir (43). Santrifüj işlemi uygulanmadan, numuneler uzun süre saklanmak istendiğinde tüpe eklenen bir koruyucu madde bu süreç boyunca kan hücrelerinden genomik DNA'nı salınımını engelleyebilmektedir. Özellikle bu süreçte cell-free DNA ${ }^{\mathrm{TM}}$ tüplerinin diğer kan tüplerine göre daha iyi performans gösterdiği saptanmıştır. Numune alınmasında kullanılan tüplerin duvarları serbest DNA'ları absorbe edebileceği için yanlış düşük sonuçlarla karşılaşılabilmektedir (45). Çift sarmal heliks formdaki DNA çok hidrofiliktir. Polipropilen, en sık kullanılan plastik mikrotüplerin ana bileşenidir ve DNA'ya bağlanabilen hidrofobik bir polimerdir(46). DNA'nın polipropilen ile etkileşimi ve onun yapısal değişikleri, tam denatürasyonu ve zincir ayrılması gösterilmiştir $(47,48)$. Bu etkileşimin kısa fragmanlı DNA'larda daha fazla olduğu gözlenmiştir (49).

\section{SONUÇ}

Özellikle kanser tanısında ve kanserin takibinde, verilen tedavinin ne derece etkili olduğunu gözlemlemede ve ileride gelişebilecek olan metastazları öngörebilmede, serbest DNA analizleri umut vaat eden bir biyobelirteçtir. Biyokimya uzmanlarının esas görevlerinden birisi, analiz edilecek numuneleri en uygun ve optimum preanalitik aşamalardan geçirip, düzgün bir analiz sürecinden sonra doğru ve güvenilir sonuçları verebilmektir. Rutin laboratuvar çalışmalarımızda da preanalitik hatalar, doğru ve güvenilir sonuçları vermemizi engelleyen başlıca hata kaynaklarıdır. Serbest DNA analizlerinin öncesinde de, analiz için en uygun materyali en doğru şekilde elde edebilmek, analiz kadar önemli olan bir aşamadır. Günümüzde hastaya minimum rahatsızlık verecek non-invaziv veya minimal invaziv diagnostik işlemler tercih edilmeye başlanmıştır. Minimal invaziv bir işlem olan kan alımı ile, hastalığın takibi kolaylaşacak, tekrarlayan görüntüleme yöntemleri ile hastaya rahatsızlık veren işlemler daha da azaltılabilecektir. Halen bazı hastalıkların kesin tanısı biyopsi ve elde edilen materyalin patolojik incelemesi ile konulmaktadır. Serbest DNA analizleri ile belirlenebilecek kesim değeri ile belki de patolojiye gerek kalmadan hastalara tanı konulabilecektir. Teorikte çok avantajlı olduğu görünen serbest DNA analizlerinin, rutin pratikte kullanılabilmesi için önceliğimiz analiz öncesi hataları tespit edip, en uygun protokolü oluşturmak olmalıdır.

\section{KAYNAKLAR}

1. Lippi, G., Banfi, G., Church, S., Cornes, M., De Carli, G., Grankvist, K., ... \& Nybo, M. (2015). Preanalytical quality improvement. In pursuit of harmony, on behalf of European Federation for Clinical Chemistry and Laboratory Medicine (EFLM) Working group for Preanalytical Phase (WG-PRE). Clinical Chemistry and Laboratory Medicine (CCLM), 53(3), 357-370. https://doi.org/10.1515/cclm2014-1051

2. Plebani, M. (2012). Quality indicators to detect preanalytical errors in laboratory testing. The Clinical Biochemist Reviews, 33(3), 85. https://doi.org/10.1016/j. cca.2013.07.033

3. Mandel, P. (1948). Les acides nucleiques du plasma sanguin chez 1 homme. CR Seances Soc Biol Fil, 142, 241-243.

4. Nawroz, H., Koch, W., Anker, P., Stroun, M., \& Sidransky, D. (1996). Microsatellite alterations in serum DNA of head and neck cancer patients. Nature medicine, 2(9), 1035. https:// doi.org/10.1038/nm0996-1035

5. Kaiser, J. (2010). Keeping tabs on tumor DNA. DOI: 10.1126/science.327.5969.1074

6. Gahan, P. B., \& Swaminathan, R. (2008). Circulating nucleic acids in plasma and serum: recent developments. Annals of the New York Academy of Sciences, 1137(1), 1-6. https:// doi.org/10.1196/annals.1448.050

7. Fleischhacker, M., \& Schmidt, B. (2007). Circulating nucleic acids (CNAs) and cancer-a survey. Biochimica et Biophysica Acta (BBA)-Reviews on Cancer, 1775(1), 181232. https://doi.org/10.1016/j.bbcan.2006.10.001

8. Schwarzenbach, H., Hoon, D. S., \& Pantel, K. (2011). Cellfree nucleic acids as biomarkers in cancer patients. Nature Reviews Cancer, 11(6), 426. https://doi.org/10.1038/nrc3066

9. Bronkhorst, A. J., Aucamp, J., \& Pretorius, P. J. (2015). Cellfree DNA: preanalytical variables. Clinica Chimica Acta, 450, 243-253. https://doi.org/10.1016/j.cca.2015.08.028

10. Leon, S. A., Shapiro, B., Sklaroff, D. M., \& Yaros, M. J. (1977). Free DNA in the serum of cancer patients and the effect of therapy. Cancer research, 37(3), 646-650. DOI: Published March 1977

11. Beau-Faller, M., Gaub, M. P., Schneider, A., Ducrocq, X., Massard, G., Gasser, B., ... \& Weitzenblum, E. (2003). Plasma DNA microsatellite panel as sensitive and tumorspecific marker in lung cancer patients. International journal of cancer, 105(3), 361-370. https://doi.org/10.1002/ijc.11079

12. Coulet, F., Blons, H., Cabelguenne, A., Lecomte, T., Laccourreye, O., Brasnu, D., ... \& Laurent-Puig, P. (2000). Detection of plasma tumor DNA in head and neck squamous cell carcinoma by microsatellite typing and p53 mutation analysis. Cancer research, 60(3), 707-711. DOI: Published February 2000

13. Maebo, A. (1990). Plasma DNA level as a tumor marker in primary lung cancer. The Japanese journal of thoracic diseases, 28(8), 1085-1091. https://doi.org/10.11389/ jjrs 1963.28.1085

14. Sozzi, G., Conte, D., Leon, M., Cirincione, R., Roz, L., Ratcliffe, C., ... \& Pierotti, M. A. (2003). Quantification 
of free circulating DNA as a diagnostic marker in lung cancer. Journal of clinical oncology, 21(21), 3902-3908.

15. Sozzi, G., Conte, D., Mariani, L., Vullo, S. L., Roz, L., Lombardo, C., ... \& Tavecchio, L. (2001). Analysis of circulating tumor DNA in plasma at diagnosis and during follow-up of lung cancer patients. Cancer research, 61(12), 4675-4678. DOI: Published June 2001

16. Gautschi, O., Bigosch, C., Huegli, B., Jermann, M., Marx, A., Chassé, E., ... \& Stahel, R. A. (2004). Circulating deoxyribonucleic acid as prognostic marker in non-smallcell lung cancer patients undergoing chemotherapy. Journal of Clinical Oncology, 22(20), 4157-4164. DOI: 10.1200/ JCO.2004.11.123

17. Fleischhacker, M., \& Schmidt, B. (2007). Circulating nucleic acids (CNAs) and cancer - a survey. Biochimica et Biophysica Acta (BBA)-Reviews on Cancer, 1775(1), 181232. https://doi.org/10.1016/j.bbcan.2006.10.001

18. Schwarzenbach, H., Hoon, D. S., \& Pantel, K. (2011). Cellfree nucleic acids as biomarkers in cancer patients. Nature Reviews Cancer, 11(6), 426. https://doi.org/10.1038/nrc3066

19. Jung, K., Fleischhacker, M., \& Rabien, A. (2010). Cell-free DNA in the blood as a solid tumor biomarker-a critical appraisal of the literature. Clinica chimica acta, 411(21-22), 1611-1624. https://doi.org/10.1016/j.cca.2010.07.032

20. Jen, J. I. N., Wu, L. I., \& Sidransky, D. (2000). An overview on the isolation and analysis of circulating tumor DNA in plasma and serum. Annals of the New York Academy of Sciences, 906(1), 8-12.

21. El Messaoudi, S., Rolet, F., Mouliere, F., \& Thierry, A. R. (2013). Circulating cell free DNA: preanalytical considerations. Clinica Chimica Acta, 424, 222-230. https:// doi.org/10.1016/j.cca.2013.05.022

22. Van der Vaart, M., \& Pretorius, P. J. (2010). Is the role of circulating DNA as a biomarker of cancer being prematurely overrated?. Clinical biochemistry, 43(1-2), 26-36. https://doi. org/10.1016/j.clinbiochem.2009.08.027

23. Zhong, X. Y., Bürk, M. R., Troeger, C., Kang, A., Holzgreve, W., \& Hahn, S. (2000). Fluctuation of maternal and fetal free extracellular circulatory DNA in maternal plasma. Obstetrics \& Gynecology, 96(6), 991-996. https://doi.org/10.1016/ S0029-7844(00)01065-6

24. Stroun, M., Anker, P., Maurice, P., Lyautey, J., Lederrey, C., \& Beljanski, M. (1989). Neoplastic characteristics of the DNA found in the plasma of cancer patients. Oncology, 46(5), 318322. https://doi.org/10.1159/000226740

25. de Kok, J. B., Hendriks, J. C., van Solinge, W. W., Willems, H. L., Mensink, E. J., \& Swinkels, D. W. (1998). Use of real-time quantitative PCR to compare DNA isolation methods. Clinical chemistry, 44(10), 2201-2204.

26. Malentacchi, F., Pizzamiglio, S., Verderio, P., Pazzagli, M., Orlando, C., Ciniselli, C. M., ... \& Gelmini, S. (2015). Influence of storage conditions and extraction methods on the quantity and quality of circulating cell-free DNA (ccfDNA): the SPIDIA-DNAplas External Quality Assessment experience. Clinical Chemistry and Laboratory Medicine (CCLM), 53(12), 1935-1942. https://doi.org/10.1515/cclm2014-1161
27. Lee, T. H., Montalvo, L., Chrebtow, V., \& Busch, M. P. (2001). Quantitation of genomic DNA in plasma and serum samples: higher concentrations of genomic DNA found in serum than in plasma. Transfusion, 41(2), 276-282. https:// doi.org/10.1046/j.1537-2995.2001.410.20276.x

28. Board, R. E., Williams, V. S., Knight, L., Shaw, J., Greystoke, A., Ranson, M., ... \& Hughes, A. (2008). Isolation and extraction of circulating tumor DNA from patients with small cell lung cancer. Annals of the New York Academy of Sciences, 1137(1), 98-107. https://doi.org/10.1196/ annals. 1448.020

29. Chan, K. A., Yeung, S. W., Lui, W. B., Rainer, T. H., \& Lo, Y. D. (2005). Effects of preanalytical factors on the molecular size of cell-free DNA in blood. Clinical chemistry, 51(4), 781-784. DOI: 10.1373/clinchem.2004.046219

30. Lui, Y. Y., Chik, K. W., Chiu, R. W., Ho, C. Y., Lam, C. W., \& Lo, Y. D. (2002). Predominant hematopoietic origin of cellfree DNA in plasma and serum after sex-mismatched bone marrow transplantation. Clinical chemistry, 48(3), 421-427.

31. Chen, Z., Fadiel, A., Naftolin, F., Eichenbaum, K. D., \& Xia, Y. (2005). Circulation DNA: biological implications for cancer metastasis and immunology. Medical hypotheses, 65(5), 956-961. https://doi.org/10.1016/j.mehy.2005.04.042

32. Harpel, P. C., Gordon, B. R., \& Parker, T. S. (1989). Plasmin catalyzes binding of lipoprotein (a) to immobilized fibrinogen and fibrin. Proceedings of the National Academy of Sciences, 86(10), 3847-3851. https://doi.org/10.1073/ pnas.86.10.3847

33. Berckmans, R. J., Nieuwland, R., Böing, A. N., Romijn, F. P., Hack, C. E., \& Sturk, A. (2001). Cell-derived microparticles circulate in healthy humans and support low grade thrombin generation. Thrombosis and haemostasis, 85(04), 639-649. DOI: $10.1055 / \mathrm{s}-0037.161 .5646$

34. Thierry, A. R., Mouliere, F., Gongora, C., Ollier, J., Robert, B., Ychou, M., ... \& Molina, F. (2010). Origin and quantification of circulating DNA in mice with human colorectal cancer xenografts. Nucleic acids research, 38(18), 6159-6175. https://doi.org/10.1093/nar/gkq421

35. Chiu, R. W., Poon, L. L., Lau, T. K., Leung, T. N., Wong, E. M., \& Lo, Y. D. (2001). Effects of blood-processing protocols on fetal and total DNA quantification in maternal plasma. Clinical chemistry, 47(9), 1607-1613.

36. Herrera, L. J., Raja, S., Gooding, W. E., El-Hefnawy, T., Kelly, L., Luketich, J. D., \& Godfrey, T. E. (2005). Quantitative analysis of circulating plasma DNA as a tumor marker in thoracic malignancies. Clinical chemistry, 51(1), 113-118. DOI: 10.1373/clinchem.2004.039263

37. Lui, Y. Y., Chik, K. W., Chiu, R. W., Ho, C. Y., Lam, C. W., \& Lo, Y. D. (2002). Predominant hematopoietic origin of cellfree DNA in plasma and serum after sex-mismatched bone marrow transplantation. Clinical chemistry, 48(3), 421-427.

38. Lam, N. Y., Rainer, T. H., Chiu, R. W., \& Lo, Y. D. (2004). EDTA is a better anticoagulant than heparin or citrate for delayed blood processing for plasma DNA analysis. Clinical chemistry, 50(1), 256-257. DOI: 10.1373/ clinchem.2003.026013 
39. Beutler, E., Gelbart, T., \& Kuhl, W. (1990). Interference of heparin with the polymerase chain reaction. Biotechniques, 9(2).

40. Xue, X., Teare, M. D., Holen, I., Zhu, Y. M., \& Woll, P. J. (2009). Optimizing the yield and utility of circulating cell-free DNA from plasma and serum. Clinica chimica acta, 404(2), 100-104. https://doi.org/10.1016/j.cca.2009.02.018

41. Jung, M., Klotzek, S., Lewandowski, M., Fleischhacker, M., \& Jung, K. (2003). Changes in concentration of DNA in serum and plasma during storage of blood samples. Clinical chemistry, 49(6), 1028-1029. DOI: 10.1373/49.6.1028

42. Swinkels, D. W., Wiegerinck, E., Steegers, E. A., \& de Kok, J. B. (2003). Effects of blood-processing protocols on cellfree DNA quantification in plasma. Clinical chemistry, 49(3), 525-526. DOI: $10.1373 / 49.3 .525$

43. Hidestrand, M., Stokowski, R., Song, K., Oliphant, A., Deavers, J., Goetsch, M., ... \& Tomita-Mitchell, A. (2012). Influence of temperature during transportation on cell-free DNA analysis. Fetal diagnosis and therapy, 31(2), 122-128. https://doi.org/10.1159/000335020

44. Fernando, M. R., Chen, K., Norton, S., Krzyzanowski, G., Bourne, D., Hunsley, B., ... \& Bassett, C. (2010). A new methodology to preserve the original proportion and integrity of cell-free fetal DNA in maternal plasma during sample processing and storage. Prenatal Diagnosis: Published in Affiliation With the International Society for Prenatal Diagnosis, 30(5), 418-424. https://doi.org/10.1002/pd.2484

45. Gaillard, C., \& Strauss, F. R. A. N. Ç. O. I. S. (2001). Eliminating DNA loss and denaturation during storage in plastic microtubes. American Clinical Laboratory, 20(2), 5254.

46. Gaillard, C., \& Strauss, F. (1998). Avoiding adsorption of DNA to polypropylene tubes and denaturation of short DNA fragments. Technical Tips Online, 3(1), 63-65.

47. Belotserkovskii, B. P., Johnston, B. H., Gaillard, C., \& Strauss, F. (1996). Polypropylene tube surfaces may induce denaturation and multimerization of DNA. SCIENCE-NEW YORK THEN WASHINGTON-, 222-222.

48. Belotserkovskii, B. P., \& Johnston, B. H. (1997). Denaturation and association of DNA sequences by certain polypropylene surfaces. Analytical biochemistry, 251(2), 251-262. https:// doi.org/10.1006/abio.1997.2249

49. Gaillard, C., \& Strauss, F. (1994). Association of poly (CA). poly (TG) DNA fragments into four-stranded complexes bound by HMG1 and 2. Science, 264(5157), 433-436. DOI: 10.1126/science. 8153633 